\title{
Review \\ Recovery of Phosphorus in Wastewater in the Form of Polyphosphates: A Review
}

\author{
Weiran Chu ${ }^{1}$, Yi Shi ${ }^{1}$ (D) and Liang Zhang ${ }^{1,2, *}$ \\ 1 Key Laboratory of Industrial Biotechnology, Ministry of Education, Jiangnan University, Wuxi 214122, China; \\ chuwr@stu.jiangnan.edu.cn (W.C.); shiyi0621@jiangnan.edu.cn (Y.S.) \\ 2 National Engineering Laboratory for Cereal Fermentation Technology, Jiangnan University, \\ Wuxi 214122, China \\ * Correspondence: zhangl@jiangnan.edu.cn; Tel.: +86-510-85918235
}

check for updates

Citation: Chu, W.; Shi, Y.; Zhang, L. Recovery of Phosphorus in Wastewater in the Form of

Polyphosphates: A Review. Processes 2022, 10, 144. https://doi.org/ $10.3390 /$ pr10010144

Academic Editors: Dimitris Zagklis and Georgios Bampos

Received: 11 December 2021

Accepted: 4 January 2022

Published: 11 January 2022

Publisher's Note: MDPI stays neutral with regard to jurisdictional claims in published maps and institutional affiliations.

Copyright: (C) 2022 by the authors. Licensee MDPI, Basel, Switzerland. This article is an open access article distributed under the terms and conditions of the Creative Commons Attribution (CC BY) license (https:// creativecommons.org/licenses/by/ $4.0 /)$.

\begin{abstract}
As non-renewable resource, the recovery and utilization of phosphorus from wastewater is an enduring topic. Stimulated by the advances in research on polyphosphates (polyP) as well as the development of Enhanced Biological Phosphorus Removal (EBPR) technology to achieve the efficient accumulation of polyP via polyphosphate accumulating organisms (PAOs), a novel phosphorus removal strategy is considered with promising potential for application in real wastewater treatment processes. This review mainly focuses on the mechanism of phosphorus aggregation in the form of polyP during the phosphate removal process. Further discussion about the reuse of polyP with different chain lengths is provided herein so as to suggest possible application pathways for this biosynthetic product.
\end{abstract}

Keywords: EBPR; PAOs; polyP; phosphorus reuse; wastewater

\section{Introduction}

With economic and industrial development, water pollution is becoming an inevitable environmental issue and eutrophication in aqueous systems normally accompanies the excessive emission of phosphorus wastewater. To eliminate the pollution, a treatment targeting the removal of phosphate from contaminated water has been adopted since the 1950s [1,2]. In general, the technologies utilized for phosphorus removal are mainly divided into three categories, which are the chemical method [3,4], biological method [5], and chemical-biological combination method [6]. Regarding chemical phosphorus removal technology, the adsorption method is suggested as being more promising since the adsorbed phosphate could be recovered for further utilization [7]. Using ferrihydrite as the adsorbent, the maximum monolayer adsorption capacities of $\mathrm{PO}_{4}{ }^{3-}$ was verified as $66.6 \mathrm{mg} \cdot \mathrm{g}^{-1}$ [8] and the adsorbed phosphorus could then be desorbed under alkaline conditions to be reused. In comparison, the biological phosphorus removal method takes advantage of the specific metabolism properties of polyphosphate accumulate organisms (PAOs) so as to excessively absorb phosphorus from wastewater and thereafter to remove $\mathrm{P}$ in the form of activated sludge [9]. Alternatively, chemical-biological combination methods have been developed for enhancing the efficacy of biological treatment by introducing specific chemical substances to prevent the PAOs from losing their phosphorus accumulation capabilities, particularly in environments that are not suitable for PAOs to thrive [10]. In consideration of the corresponding properties of the above phosphorus removal technologies, decisions on the actual treatment strategies are made based on the actual water quality conditions as well as economic and environmental requirements.

Although current wastewater treatment methods can normally realize efficient phosphorus removal from the water, attention should also be paid to the provision of promising pathways for the recovery and reuse of P. Phosphorus is an element that cannot be released from the system through biological metabolism and typical wastewater treatment strategies 
mainly remove phosphate from water by transferring or accumulating phosphorus in a form that can be separated. The limited utilization efficacy of phosphorus-rich waste produced during the above treatment process leads to a lost resource, particularly considering that the existing phosphate reserves will be exhausted in the next 50-100 years at the current rate of extraction [11]. In this regard, strategies with the potential of removing $\mathrm{P}$ from the system in a form that could be further applied are receiving increasing interest. Among the available P removal strategies, Enhanced Biological Phosphorus Removal (EBPR) with PAOs as the working units is considered as the best candidate for achieving $P$ removal and reuse simultaneously. As the drivers of this biological P removal process, PAOs generate $P$ from their surroundings and aggregate single phosphate to form long-chain polyphosphate (polyP) [12], which is a type of polymer consisting of tens to hundreds of phosphate residues. Linked by phosphoanhydride bonds, polyP has been found in abundance in all cells in nature and it has been suggested that it is unique in its likely role in the origin and survival of species $[13,14]$. Recent studies also revealed that polyP could act as a storage for and generator of metabolic energy in the extracellular matrix [15] and play a role in osteoblasts for promoting cartilage mineralization [16]. In addition, polyP with different chain lengths was verified as having an impact on the activity of blood coagulation factors [17] and thus, affecting the endogenous blood clotting ability in animals [18]. The strong chelating ability of long-chain polyP could enable it to play a role in food preservation and antibacterial products [19]. Given the application potential of polyP, recovering $\mathrm{P}$ from wastewater via PAOs to obtain biosynthetic polyP for further utilization is considered to be a possible strategy for improving the efficacy of $\mathrm{P}$ reuse. Herein, reviews and a discussion are provided for the purpose of suggesting a feasible pathway to collect, recycle, and reuse phosphorus from wastewater in the form of polyP.

\section{Enrichment of PolyP in PAOs during EBPR Process}

EBPR is a biological phosphorus removal technology that was developed in the 1970s and is now widely used in sewage treatment plants around the world [20]. Relying on PAOs or denitrifying phosphorous accumulating bacteria (DPAOs) [21], EBPR technology can remove $\mathrm{P}$ by having the free $\mathrm{P}$ absorbed by functional microbes for the purpose of growth and accumulated within the cell in the form of polyphosphate particles [22]. The traditional EBPR process diagram is illustrated in Figure 1. Generally, by alternating anaerobic and aerobic conditions, PAOs absorb the volatile fatty acids (VFAs) in sewage during the anaerobic stage and store them as poly- $\beta$-hydroxyalkanoic acid (PHA). This stored energy substance then serves as the carbon source and provides the energy required for the phosphorus accumulation and polyphosphate synthesis in the sewage by the PAOs during the aerobic stage $[23,24]$. $P$ is subsequently removed from the system when the abovementioned phosphorus-containing microorganisms are discharged as phosphorusrich sludge from the EBPR system [25]. The content of polyphosphate can be as high as $20 \%$ of its dry weight in PAO-rich sludge [26], while it accounts for no more than $2 \%$ in normal wastewater treatment sludge. Hence, this phosphorus-rich sludge produced in the EBPR process could be considered as having the potential to be applied as the resource for phosphorus collection and further reuse. In addition, efforts could be put into introducing PAOs with enhanced capabilities for phosphate accumulation so as to have more P recycled in the form of polyP.

Although modern wastewater treatment is normally driven by biological metabolic activity, it is still an energy- and time-consuming process. As such, how to make a profit in recycling the resource from wastewater has been assessed [27,28]. Egle et al. [29] summarized the traditional EBPR system for the treatment and recovery of phosphorus in wastewater and believed that the recovery of $70 \%$ to $90 \%$ of the phosphorus in the sludge in the form of ash was the best trade-off between cost and benefit. With the limited recovery rate of the traditional phosphorus removal process, the development of strategies that recover dissolved phosphorus more efficiently in the form of polyP is considered to 
be beneficial with respect to the techno-economic feasibility by taking into account the application potential of this biosynthetic product.

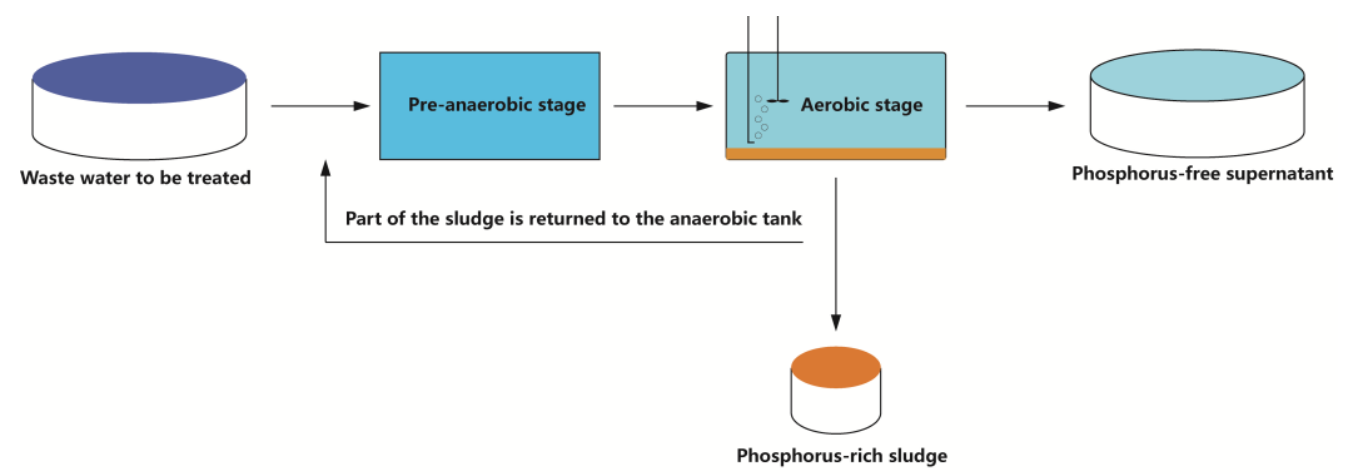

Figure 1. Diagram of traditional EBPR phosphorus removal method.

\subsection{Factors Affecting PolyP Accumulation in PAOs during EBPR Process}

\subsubsection{Glucose Accumulating Organisms (GAOs)}

In the actual sewage treatment process, the phosphorus content of the sewage is generally less than $10 \mathrm{mg} \mathrm{P} / \mathrm{L}[30,31]$ and the concentration of $\mathrm{P}$ in the effluent is normally as low as $0.1 \mathrm{mg} \mathrm{P} / \mathrm{L}$ due to having most of the phosphorus contained within the sewage influent removed during the aerobic stage [32,33]. However, the phosphorus removal efficiency of EBPR could be affected by external factors, the most influential of which is the competitive effect brought by GAOs [34]. GAOs have almost the same metabolic processes as PAOs, and the most significant difference is that the energy source of the matrix is absorbed in the aerobic phase [35]. As shown in Figure 2, GAOs decompose glycogen in the body during the anaerobic stage to provide energy and restore power to be used for organic matter absorbance and polyhydroxyalkanoates(PHA) synthesis in the cell. During the aerobic stage, this PHA is decomposed for glycogen synthesis and the maintenance of microorganism activity instead of having phosphorus accumulation. Due to the competitive relationship between GAOs and PAOs for the available VAFs, the EPBR system should be operated under conditions that are conducive to the growth of PAOs and hence, enhance the competitive advantages of PAOs over GAOs [36]. Under such conditions, the effect of GAOs on the dephosphorization efficacy would be eliminated and more phosphorus could then be enriched in the form of polyP.

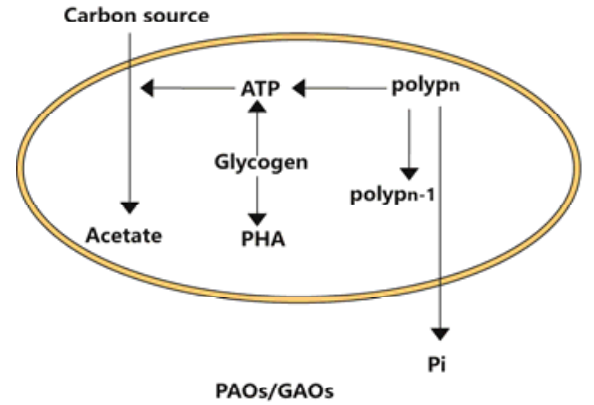

PAOS/GAOs

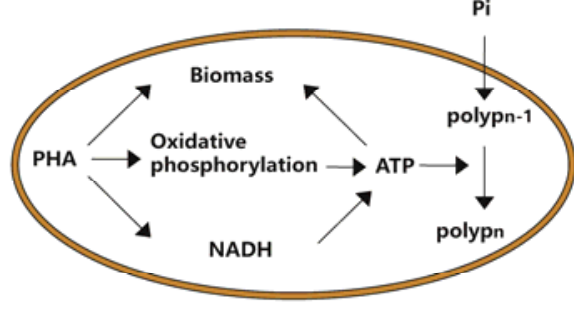

PAOs

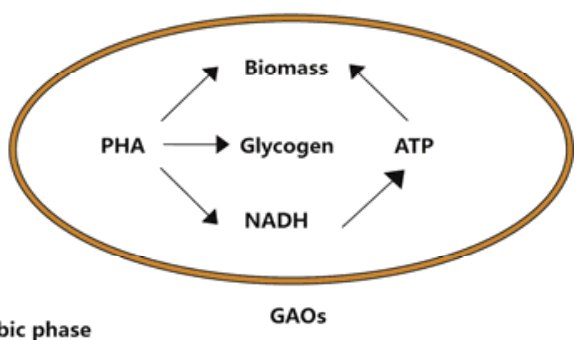

Figure 2. Anaerobic/Aerobic metabolism model of PAOs/GAOs. 


\subsubsection{Carbon Source}

Among all environmental factors, the carbon source is considered to have the greatest impact on the efficiency of polyP synthesis in PAOs since it provides the support for PAOs to carry out all required activities. The variation in utilization rates for different carbon sources make it important to consider the type of carbon source that is available in the system as competition may occur between PAOs and GAOs if the organic substance cannot be metabolized efficiently by PAOs. To eliminate the competition, previous studies have indicated that acetate and propionate are appropriate energy sources that allow PAOs to overcome the interference brought by other competitors in the EBPR system [37-39]. When acetate is the main carbon source, the acetate permease within the PAOs enables the microbes to maintain a higher acetate adsorption rate during the phosphate accumulation metabolism (PAM) process than that in the glycogen accumulation metabolism (GAM) process performed by GAOs, even with a low acetate concentration [40]. With this source, PAOs can remove small amounts of acetic acid by maintaining superiority over acetic acid absorption activity [41]. Propionate, as another popular carbon substrate, accounts for 24 to $33 \%$ of septic tank municipal wastewater [38]. Without transferring to an intermediate, propionate can be absorbed by PAOs immediately and converted into propionyl-CoA, which can then further participate in the glycogen hydrolyzed acetyl and other metabolic processes. Coenzyme A is reduced and condensed to form PHA, which serves as a type of energy source for the formation of polyphosphate in the eutrophic stage [42]. In fact, compared to acetate, less energy and phosphorus release are required for the utilization of propionate by PAOs and hence, propionate is suggested to be the carbon source that would favor the phosphate accumulation metabolism process in PAOs [43].

In addition to the two abovementioned carbon substrates, alternative carbon sources can also be selected according to actual conditions. For instance, glucose or its polymers can replace PHA as the energy source for the absorption and polyP synthesis via PAOs. However, it should be noted that the introduction of glucose may induce glycogen metabolism activity in GAOs, resulting in a reduction in polyP production by deteriorating the EBPR process [44]. Ethanol is another economically sustainable carbon source with potential as an EBPR substrate, although its application is specific to EBPR systems composed of PAOs with acetaldehyde dehydrogenase [45]. Another reportedly valid carbon source is glycerol, which is also often used as an external carbon source for denitrification. It normally cannot induce phosphate accumulation metabolism activity in EBPR unless it is fermented into VFA in advance [46]. In addition, research also revealed that butyric acid cannot be metabolized well by GAOs at a high temperature $\left(30^{\circ} \mathrm{C}\right)$, thereby providing PAOs with a competitive advantage [47]. In actual sewage treatment, the production of polyP is mainly dependent on the turnover rate of PHB and polyphosphate. To obtain a larger amount of recycled polyP, the carbon substrate should be chosen for the purpose of having PAOs as the dominant microbial community as well as providing advantageous conditions for ensuring sufficient energy is available for the synthesis of polyphosphate.

\subsection{Inspiration of P Recovery in the Form of PolyP by One-Step Phosphorus Removal}

With the continuous in-depth research on PAOs, researchers are beginning to reflect on whether phosphorus recycling is valid and efficient within the traditional EBPR system [48]. Rather than being operated by multiple steps in EBPR, one-step phosphorus removal by sequential batch membrane bioreactors (SBMBRs) is suggested as being a more promising means by which the simultaneous removal and reuse of phosphorus may be realized [22]. Relying on the SBMBRs, polyP accumulation could be improved via genetic technology. By increasing the amount of genes encoding the Pi-specific transport system (phoU) [49] or having the overexpression of polyphosphate kinase (PPK1) [50], engineering bacteria with enhanced capabilities for Pi transport or polyP accumulation have been constructed. Until now, the overall amount of polyP synthesized during the phosphorus removal process was reported to account for about $12.7 \%$ of the dry cell weight [22], indicating the great application potential for the aims of phosphorus recovery in the form of polyP. 
Without setting pre-anaerobic zones for VFA production, the abovementioned progress in constructing bacteria with the ability to accumulate phosphate under aerobic conditions suggests a simpler strategy for phosphorus removal along with effective polyP synthesis by PAOs [51].

\section{PolyP Recovery from Phosphorus Removal System}

Traditionally, the phosphorus-rich sludge produced from EBPR is directly used as fertilizer or dehydrated for incineration [52,53], although chemical and biological pollution accompany these operations. Instead, there may be less of an environmental impact and more economical benefits if polyP is recovered properly from the phosphorus-rich sludge. To develop an applicable polyP recovery process, the effect of the treatment on the type and chain length of polyP should be taken into consideration as the performance of polyP is largely dependent on these properties [54]. In general, the type of polyP is determined by the type of PAOs and the culture conditions, while the recovery method will affect the chain length of the obtained polyP. Herein, two recovery strategies are reviewed to provide information regarding the practical requirements for further polyP reuse.

\subsection{Organic Reagent Precipitation Method}

Methods for having polyP with varying chain lengths separated from microbes were preliminarily developed for the purpose of investigating its possible function involved in the microorganism metabolic process. To release polyP from the cell and remove the interference of protein, trichloroacetic acid was first applied and was followed by the continuous extraction of polyP using a combination of saturated sodium perchlorate and sodium hydroxide [55-60]. Kulaev et al. (1966) further optimized the protocol by replacing trichloroacetic acid with perchloric acid [61] and other adjustments were also performed in the following decades, depending on the specific goal of the research [62-66]. Among all the developed organic reagent precipitation methods, the use of ethanol and barium ions as the precipitation agents was reported as having the highest recovery rate [67-69].

Rather than recovering polyP with a wide range of chain lengths, research also tended to isolate polyP as an intracellular polyanion with a long phosphate backbone by developing the approach of nucleic extraction. In this method, cells are disrupted by chaotropic substances or acidic phenol beads, and the products are then purified with chloroform washing or silica gel column [70,71]. Contrasting with the previous strategy, this method is mainly targeted at polyP consisting of more than 60 phosphate residues.

\subsection{High Temperature Calcination Method}

Compared to the use of organic reagents to fractionate and purify polyP, the utilization of high-temperature calcination to extract the crude polyP with mixed chain lengths from sludge in wastewater treatment plants is considered to be a more economical and efficient approach, especially concerning polyP recovered from SBMBRs [29,72]. Relying on the thermal stability of polyP, organic components within the sludge or cell culture are oxidized thoroughly at a high temperature and the remaining ashes are collected for further purification to obtain polyP as the final product [72]. Generally, this method involves several processes, beginning with the recovery of PAOs from the phosphorus removal systems by having the sludge dehydrated. The obtained material is then calcined at a high temperature to remove most of the biological macromolecules, such as nucleic acid and protein. The remaining ashes are considered as the crude polyP and the pure product is collected by introducing further purification operations. In combination with the separation method described in Section 3.1, polyP with different chain lengths can be recovered thereafter.

\section{Application Prospects of Biosynthetic PolyP}

Until now, although polyP has been suggested as being a significant participant in various biochemical activities, such as being the activator of mitochondrial respiration regulation [57,58], the accelerating inducer of HUVEC endothelial cell tube formation [59], and 
the scaffold for multifunctional polyanionic protein [60], the mechanism of the biosynthesis of polyP in mammals has remained uncertain [18]. Among the various scattered functions, applying polyP as a generator and storage of metabolizable energy in the extracellular matrix (ECM) [73] in the osteoblast-led bone mineralization process [16] and supplying polyP as a functional substance for preparing procoagulants and anticoagulants in endogenous coagulation pathways $[74,75]$ are considered as the most promising application directions of biosynthetic polyP.

\subsection{Application of PolyP for Bone Reparation}

PolyP has been proven to be a source of inorganic phosphate, which is required in the process of bone mineralization [76,77]. Performed by alkaline phosphatase (ALP) and mediated polyP hydrolysis (Figure 3), polyP could be applied as the activator to convert the initial transformation of amorphous calcium carbonate deposits into amorphous calcium phosphate [16]. During the process of bone or cartilage formation, the forming of blood vessels is a crucial step for tissue construction and repair. At this stage, the orientation, guidance, and ring formation of the endothelial cells need to be mediated by adenosine triphosphate (ATP) in the ECM, while polyP could be used as the back-up storage of highenergy phosphate bonds for supplying the energy required during this process. Studies have found that calcium phosphate cement (CPC) made a significant contribution to osteogenic differentiation and bone regeneration $[73,78]$. However, information about the effect of different salt types and different chain lengths of polyP on osteoblasts is limited. As such, further research and investigation is needed.

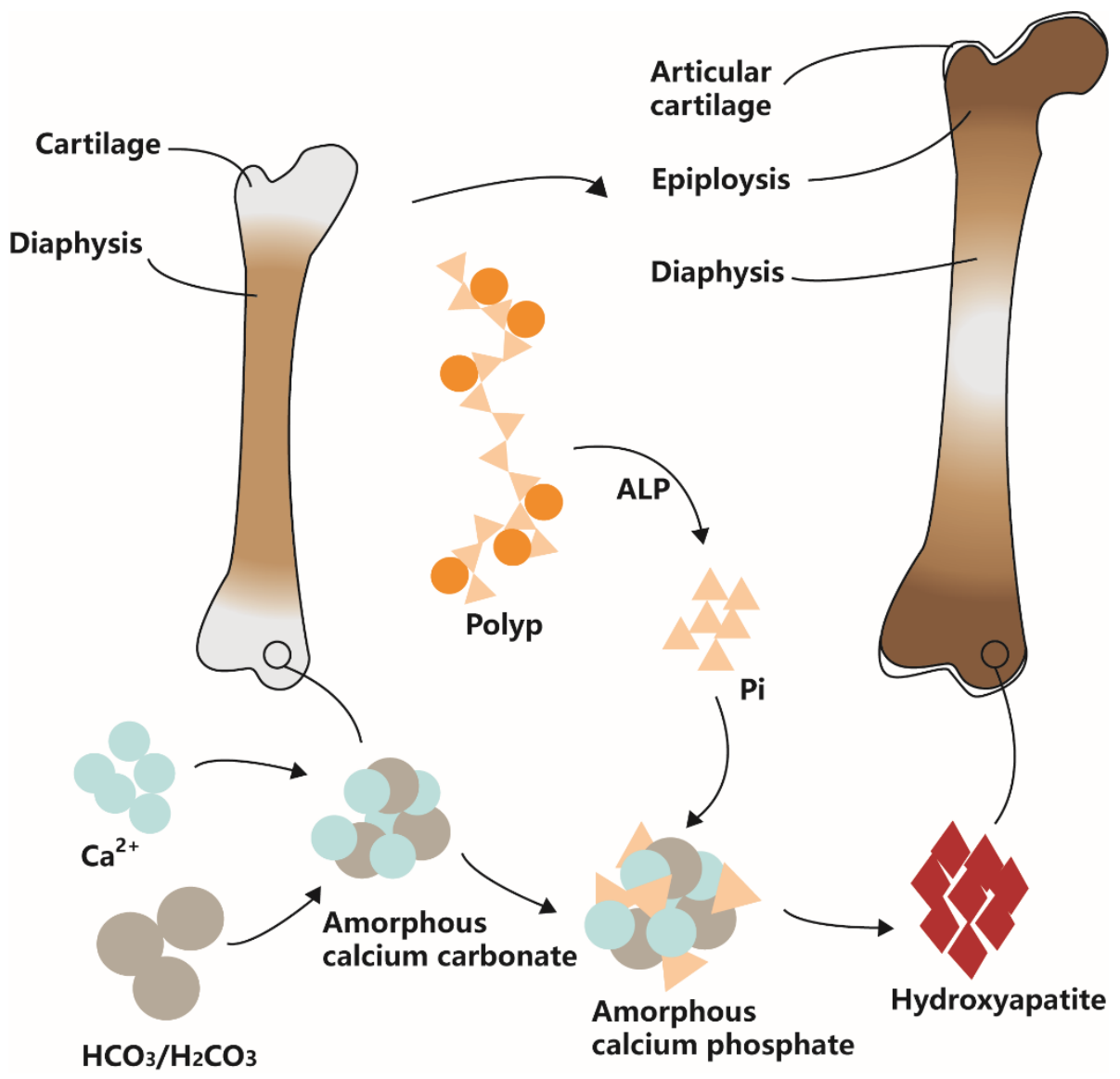

Figure 3. PolyP acts as a phosphate reserve during cartilage mineralization.

\subsection{Application of PolyP for Endogenous Coagulation}

Released from platelets, internal polyP was found to promote coagulation after the activation of coagulation factor XII (FXII) [74]. In addition, the introduction of external 
calcium-containing polyP was also suggested as having the potential to enhance the abovementioned process [75]. When taking the chain length of polyP into consideration, the long-chain sodium polyP (45 type) revealed an inhabitation effect on blood clotting and hence, was suggested as a promising candidate for use as an anticoagulant [17]. However, despite the preliminary confirmation of the effectiveness of polyP for coagulation, it is still unclear whether there is a relationship between the properties of polyP and the resulting thrombosis effect. To fulfil this gap, research should focus on the impact of polyP with different chain lengths and salt types on coagulation and the mechanism may then be explained to some extent.

\section{Conclusions}

The development of new technology or optimization of current phosphorus removing strategies is an irreversible trend for realizing the effective recovery of phosphorus from wastewater. With the successful construction of engineering bacteria by introducing functional genes related with phosphorus accumulation, the use of SBMBRs to simplify the phosphorus removing process and recover the biosynthetic polyP from treatment plants is becoming promising via proper purification methods. We suggest further investigation into the mechanism of the specific influence of polyP properties on potential application areas so as to provide more fundamental information regarding the rational and practical utilization of recycled polyP.

Author Contributions: Writing—original draft preparation, W.C.; writing—review and editing, Y.S.; supervision, L.Z. All authors have read and agreed to the published version of the manuscript.

Funding: This research was supported by the National Key Research and Development Program of China (2018YFA0900300, 2021YFC2100300).

Informed Consent Statement: Informed consent was obtained from all subjects involved in the study.

Conflicts of Interest: The authors declare no conflict of interest.

\section{References}

1. Morse, G.K.; Brett, S.W.; Guy, J.A.; Lester, J.N. Review: Phosphorus removal and recovery technologies. Sci. Total Environ. 1998, 212, 69-81. [CrossRef]

2. Carpenter, S.R.; Caraco, N.F.; Correll, D.L.; Howarth, R.W.; Sharpley, A.N.; Smith, V.H. Nonpoint pollution of surface waters with phosphorus and nitrogen. Ecol. Appl. 1998, 8, 559-568. [CrossRef]

3. Ifelebuegu, A.O.; Ojo, P. Modelling the effects of ferric salt dosing for chemical phosphorus removal on the settleability of activated sludge. J. Environ. Chem. Eng. 2019, 7, 103256. [CrossRef]

4. Thistleton, J.; Berry, T.A.; Pearce, P.; Parsons, S.A. Mechanisms of Chemical Phosphorus Removal II. Process Saf. Environ. Prot. 2002, 80, 265-269. [CrossRef]

5. Mao, Y.; Xiong, R.; Gao, X.; Jiang, L.; Peng, Y.; Xue, Y. Analysis of the Status and Improvement of Microalgal Phosphorus Removal from Municipal Wastewater. Processes 2021, 9, 1486. [CrossRef]

6. Novais, S.V.; Zenero, M.D.O.; Barreto, M.S.C.; Montes, C.R.; Cerri, C.E.P. Phosphorus removal from eutrophic water using modified biochar. Sci. Total Environ. 2018, 633, 825-835. [CrossRef]

7. Chaochun, T.; Huimin, C.; Ming, L.; Xin, Y. Research progress in the use of adsorption for dephosphorization. Ind. Water Treat. 2015, 37, 1-4.

8. Ajmal, Z.; Muhmood, A.; Usman, M.; Kizito, S.; Lu, J.; Dong, R.; Wu, S. Phosphate removal from aqueous solution using iron oxides: Adsorption, desorption and regeneration characteristics. J. Colloid Interface Sci. 2018, 528, 145-155. [CrossRef]

9. Izadi, P.; Izadi, P.; Eldyasti, A. Design, operation and technology configurations for enhanced biological phosphorus removal (EBPR) process: A review. Rev. Environ. Sci. Bio/Technol. 2020, 19, 561-593. [CrossRef]

10. Ji, B.; Zhu, L.; Wang, S.; Qin, H.; Ma, Y.; Liu, Y. A novel micro-ferrous dosing strategy for enhancing biological phosphorus removal from municipal wastewater. Sci. Total Environ. 2020, 704, 135453. [CrossRef]

11. Zhang, M.; Zheng, P.; Abbas, G.; Chen, X. Partitionable-space enhanced coagulation (PEC) reactor and its working mechanism: A new prospective chemical technology for phosphorus pollution control. Water Res. 2014, 49, 426-433. [CrossRef]

12. Mino, T.; Van Loosdrecht, M.C.M.; Heijnen, J.J. Microbiology and biochemistry of the enhanced biological phosphate removal process. Water Res. 1998, 32, 3193-3207. [CrossRef]

13. Rao, N.N.; Gómez-García, M.R.; Kornberg, A. Inorganic polyphosphate: Essential for growth and survival. Annu. Rev. Biochem. 2009, 78, 605-647. [CrossRef] 
14. Brown, M.R.; Kornberg, A. The long and short of it-polyphosphate, PPK and bacterial survival. Trends Biochem. Sci. 2008, 33, 284-290. [CrossRef] [PubMed]

15. Muller, W.E.G.; Schroder, H.C.; Wang, X. Inorganic Polyphosphates As Storage for and Generator of Metabolic Energy in the Extracellular Matrix. Chem. Rev. 2019, 119, 12337-12374. [CrossRef] [PubMed]

16. Wang, X.; Schroder, H.C.; Muller, W.E.G. Amorphous polyphosphate, a smart bioinspired nano-/bio-material for bone and cartilage regeneration: Towards a new paradigm in tissue engineering. J. Mater. Chem. B 2018, 6, 2385-2412. [CrossRef]

17. Yang, X.; Wan, M.; Liang, T.; Peng, M.; Chen, F. Synthetic polyphosphate inhibits endogenous coagulation and platelet aggregation in vitro. Biomed. Rep. 2017, 6, 57-62. [CrossRef]

18. Desfougeres, Y.; Saiardi, A.; Azevedo, C. Inorganic polyphosphate in mammals: Where's Wally? Biochem. Soc. Trans. 2020, 48, 95-101. [CrossRef]

19. Maier, S.K.; Scherer, S.; Loessner, M.J. Long-Chain Polyphosphate Causes Cell Lysis and Inhibits Bacillus cereus Septum Formation, Which Is Dependent on Divalent Cations. Appl. Environ. Microbiol. 1999, 65, 3942-3949. [CrossRef] [PubMed]

20. Barnard, J.L. Biological nutrient removal without the addition of chemicals. Water Res. 1975, 9, 485-490. [CrossRef]

21. Li, H.; Zhong, Y.; Huang, H.; Tan, Z.; Sun, Y.; Liu, H. Simultaneous nitrogen and phosphorus removal by interactions between phosphate accumulating organisms (PAOs) and denitrifying phosphate accumulating organisms (DPAOs) in a sequencing batch reactor. Sci. Total Environ. 2020, 744, 140852. [CrossRef] [PubMed]

22. Wang, X.; Wang, X.; Hui, K.; Wei, W.; Zhang, W.; Miao, A.; Xiao, L.; Yang, L. Highly Effective Polyphosphate Synthesis, Phosphate Removal, and Concentration Using Engineered Environmental Bacteria Based on a Simple Solo Medium-Copy Plasmid Strategy. Environ. Sci. Technol. 2018, 52, 214-222. [CrossRef] [PubMed]

23. Wang, L.; Shen, N.; Oehmen, A.; Zhou, Y. The impact of temperature on the metabolism of volatile fatty acids by polyphosphate accumulating organisms (PAOs). Environ. Res. 2020, 188, 109729. [CrossRef]

24. Ong, Y.H.; Chua, A.S.M.; Fukushima, T.; Ngoh, G.C.; Shoji, T.; Michinaka, A. High-temperature EBPR process: The performance, analysis of PAOs and GAOs and the fine-scale population study of Candidatus "Accumulibacter phosphatis". Water Res. 2014, 64, 102-112. [CrossRef] [PubMed]

25. Kristiansen, R.; Nguyen, H.T.; Saunders, A.M.; Nielsen, J.L.; Wimmer, R.; Le, V.Q.; McIlroy, S.J.; Petrovski, S.; Seviour, R.J.; Calteau, A.; et al. A metabolic model for members of the genus Tetrasphaera involved in enhanced biological phosphorus removal. ISME J. 2013, 7, 543-554. [CrossRef]

26. Metcalf \& Eddy; Abu-Orf, M.; Bowden, G.; Burton, F.L.; Pfrang, W.; Stensel, H.D.; Tchobanoglous, G.; Tsuchihashi, R. AECOM. In Wastewater Engineering: Treatment and Resource Recovery; McGraw Hill Education: New York, NY, USA, 2014.

27. Li, B.; Udugama, I.A.; Mansouri, S.S.; Yu, W.; Baroutian, S.; Gernaey, K.V.; Young, B.R. An exploration of barriers for commercializing phosphorus recovery technologies. J. Clean. Prod. 2019, 229, 1342-1354. [CrossRef]

28. Chrispim, M.C.; Scholz, M.; Nolasco, M.A. Phosphorus recovery from municipal wastewater treatment: Critical review of challenges and opportunities for developing countries. J. Environ. Manag. 2019, 248, 109268. [CrossRef]

29. Egle, L.; Rechberger, H.; Krampe, J.; Zessner, M. Phosphorus recovery from municipal wastewater: An integrated comparative technological, environmental and economic assessment of P recovery technologies. Sci. Total Environ. 2016, 571, 522-542. [CrossRef]

30. Kim, J.-O.; Chung, J. Implementing chemical precipitation as a pretreatment for phosphorus removal in membrane bioreactorbased municipal wastewater treatment plants. KSCE J. Civ. Eng. 2014, 18, 956-963. [CrossRef]

31. Qiu, G.; Ting, Y.P. Direct phosphorus recovery from municipal wastewater via osmotic membrane bioreactor (OMBR) for wastewater treatment. Bioresour. Technol. 2014, 170, 221-229. [CrossRef]

32. Gautam, R.K.; Banerjee, S.; Gautam, P.K.; Chattopadhyaya, M. Remediation technologies for phosphate removal from wastewater: An overview. Adv. Environ. Res. 2014, 36, 177-200.

33. Gebremariam, S.Y.; Beutel, M.W.; Christian, D.; Hess, T.F. Research advances and challenges in the microbiology of enhanced biological phosphorus removal-A critical review. Water Environ. Res. 2011, 83, 195-219. [CrossRef] [PubMed]

34. Chen, J.; Wang, J.; Wang, X.; Lv, Y.; Li, D.; Hou, J.; He, X. Strengthening anoxic glycogen consumption in SNEDPR-CW as a strategy to control PAO-GAO competition under carbon limited condition. Chemosphere 2021, 288, 132617. [CrossRef]

35. Nielsen, P.H.; McIlroy, S.J.; Albertsen, M.; Nierychlo, M. Re-evaluating the microbiology of the enhanced biological phosphorus removal process. Curr. Opin. Biotechnol. 2019, 57, 111-118. [CrossRef]

36. Lopez-Vazquez, C.M.; Oehmen, A.; Hooijmans, C.M.; Brdjanovic, D.; Gijzen, H.J.; Yuan, Z.; van Loosdrecht, M.C. Modeling the PAO-GAO competition: Effects of carbon source, $\mathrm{pH}$ and temperature. Water Res. 2009, 43, 450-462. [CrossRef]

37. Vargas, M.; Guisasola, A.; Artigues, A.; Casas, C.; Baeza, J.A. Comparison of a nitrite-based anaerobic-anoxic EBPR system with propionate or acetate as electron donors. Process Biochem. 2011, 46, 714-720. [CrossRef]

38. Lv, X.-M.; Shao, M.-F.; Li, C.-L.; Li, J.; Xia, X.; Liu, D.-Y. Bacterial diversity and community structure of denitrifying phosphorus removal sludge in strict anaerobic/anoxic systems operated with different carbon sources. J. Chem. Technol. Biotechnol. 2014, 89, 1842-1849. [CrossRef]

39. Hsu, C.-H.; Chang, W.-C.; Chen, J.-J.; Wu, J.-S. Comparing the long-term effect of high P/COD influent on enhancement of phosphate-accumulating organisms between acetate- and propionate-fed reactors. J. Chem. Technol. Biotechnol. 2013, 88, 1071-1079. [CrossRef] 
40. Schuler, A.J.; Jenkins, D. Enhanced biological phosphorus removal from wastewater by biomass with different phosphorus contents, part II: Anaerobic adenosine triphosphate utilization and acetate uptake rates. Water Environ. Res. 2003, 75, 499-511. [CrossRef] [PubMed]

41. Ahmed, Z.; Lim, B.R.; Cho, J.; Song, K.G.; Kim, K.P.; Ahn, K.H. Biological nitrogen and phosphorus removal and changes in microbial community structure in a membrane bioreactor: Effect of different carbon sources. Water Res. 2008, 42, 198-210. [CrossRef]

42. Oehmen, A.; Zeng, R.J.; Yuan, Z.; Keller, J. Anaerobic metabolism of propionate by polyphosphate-accumulating organisms in enhanced biological phosphorus removal systems. Biotechnol. Bioeng. 2005, 91, 43-53. [CrossRef]

43. Carvalheira, M.; Oehmen, A.; Carvalho, G.; Reis, M.A.M. The effect of substrate competition on the metabolism of polyphosphate accumulating organisms (PAOs). Water Res. 2014, 64, 149-159. [CrossRef]

44. Wang, Y.; Jiang, F.; Zhang, Z.; Xing, M.; Lu, Z.; Wu, M.; Yang, J.; Peng, Y. The long-term effect of carbon source on the competition between polyphosphorus accumulating organisms and glycogen accumulating organism in a continuous plug-flow anaerobic/aerobic (A/O) process. Bioresour. Technol. 2010, 101, 98-104. [CrossRef]

45. Skennerton, C.T.; Barr, J.J.; Slater, F.R.; Bond, P.L.; Tyson, G.W. Expanding our view of genomic diversity in Candidatus Accumulibacter clades. Environ. Microbiol. 2015, 17, 1574-1585. [CrossRef]

46. Yuan, Q.; Sparling, R.; Lagasse, P.; Lee, Y.; Taniguchi, D.; Oleszkiewicz, J. Enhancing biological phosphorus removal with glycerol. Water Sci. Technol. 2010, 61, 1837-1843. [CrossRef] [PubMed]

47. Wang, L.; Liu, J.; Oehmen, A.; Le, C.; Geng, Y.; Zhou, Y. Butyrate can support PAOs but not GAOs in tropical climates. Water Res. 2021, 193, 116884. [CrossRef] [PubMed]

48. Barnard, J.L.; Dunlap, P.; Steichen, M. Rethinking the mechanisms of biological phosphorus removal: Barnard et al. Water Environ. Res. 2017, 89, 2043-2054. [CrossRef]

49. Kato, J.; Yamada, K.; Muramatsu, A.; Hardoyo; Ohtake, H. Genetic improvement of Escherichia coli for enhanced biological removal of phosphate from wastewater. Appl. Environ. Microbiol. 1993, 59, 3744-3749. [CrossRef] [PubMed]

50. Hardoyo; Yamada, K.; Shinjo, H.; Kato, J.; Ohtake, H. Production and release of polyphosphate by a genetically engineered strain of Escherichia coli. Appl. Environ. Microbiol. 1994, 60, 3485-3490. [CrossRef]

51. Cokro, A.A.; Law, Y.; Williams, R.B.H.; Cao, Y.; Nielsen, P.H.; Wuertz, S. Non-denitrifying polyphosphate accumulating organisms obviate requirement for anaerobic condition. Water Res. 2017, 111, 393-403. [CrossRef]

52. Erdincler, A.; Seyhan, L. Agricultural use of municipal wastewater sludges: Phosphorus availability of biological excess phosphorus removal sludges. Water Sci. Technol. 2006, 54, 131-138. [CrossRef]

53. Kahiluoto, H.; Kuisma, M.; Ketoja, E.; Salo, T.; Heikkinen, J. Phosphorus in manure and sewage sludge more recyclable than in soluble inorganic fertilizer. Environ. Sci Technol 2015, 49, 2115-2122. [CrossRef]

54. Wang, D.; Li, Y.; Cope, H.A.; Li, X.; He, P.; Liu, C.; Li, G.; Rahman, S.M.; Tooker, N.B.; Bott, C.B.; et al. Intracellular polyphosphate length characterization in polyphosphate accumulating microorganisms (PAOs): Implications in PAO phenotypic diversity and enhanced biological phosphorus removal performance. Water Res. 2021, 206, 117726. [CrossRef] [PubMed]

55. Langen, P.; Liss, E. Über die Polyphosphate der Hele. Naturwissenschaften 1958, 45, 191. [CrossRef]

56. Langen, P.; Liss, E. Uber bildung und umsatz der polyphosphate der hefe. Biochem. Z. 1958, 330, 455-466.

57. Liss, E.; Langen, P. Zur Charakterisierung der Polyphosphate der Hefe. Naturwissenschaften 1959, 46, 151. [CrossRef]

58. Langen, P.; Liss, E. Differenzierung des Orthophosphates der Hefezelle. Biochem. Z. 1960, 332, 403-406.

59. Liss, E.; Langen, P. Uber ein hochmolekulares Polyphosphat der Hefe. Biochem. Z. 1960, 333, 193-201.

60. Liss, E.; Langen, P. Versuche zur polyphosphat-überkompensation in hefezellen nach phosphatverarmung. Arch. Mikrobiol. 1962, 41, 383-392. [CrossRef]

61. Kulaev, I.; Krasheninnikov, I.; Kokurina, N. On the Localization of Inorganic Polyphosphates and Nucleotides in Neurospora Crassa Mycelium. Biokhimiia 1966, 31, 850-859.

62. Vagabov, V.; Trilisenko, L.; Kulaev, I. Dependence of inorganic polyphosphate chain length on the orthophosphate content in the culture medium of the yeast Saccharomyces cerevisiae. Biochem. N. Y. Engl. Transl. Biokhimiya 2000, 65, 349-354.

63. Vagabov, V.; Trilisenko, L.; Kulakovskaya, E.; Kulaev, I. Study of the content of inorganic polyphosphates in Saccharomyces cerevisiae grown on different carbon sources with different O 2 concentrations in the medium. Microbiology 2008, 77, 541-546. [CrossRef]

64. Vagabov, V.M.; Trilisenko, L.V.; Kulakovskaya, T.V.; Kulaev, I.S. Effect of a carbon source on polyphosphate accumulation in Saccharomyces cerevisiae. FEMS Yeast Res. 2008, 8, 877-882. [CrossRef] [PubMed]

65. Breus, N.A.; Ryazanova, L.P.; Dmitriev, V.V.; Kulakovskaya, T.V.; Kulaev, I.S. Accumulation of phosphate and polyphosphate by Cryptococcus humicola and Saccharomyces cerevisiae in the absence of nitrogen. FEMS Yeast Res. 2012, 12, 617-624. [CrossRef]

66. Andreeva, N.; Ryazanova, L.; Dmitriev, V.; Kulakovskaya, T.; Kulaev, I. Adaptation of Saccharomyces cerevisiae to toxic manganese concentration triggers changes in inorganic polyphosphates. FEMS Yeast Res. 2013, 13, 463-470. [CrossRef]

67. Clark, J.E.; Beegen, H.; Wood, H.G. Isolation of intact chains of polyphosphate from "Propionibacterium shermanii" grown on glucose or lactate. J. Bacteriol. 1986, 168, 1212-1219. [CrossRef] [PubMed]

68. Mullan, A.; Quinn, J.P.; McGrath, J.W. A nonradioactive method for the assay of polyphosphate kinase activity and its application in the study of polyphosphate metabolism in Burkholderia cepacia. Anal. Biochem. 2002, 308, 294-299. [CrossRef] 
69. Christ, J.J.; Blank, L.M. Analytical polyphosphate extraction from Saccharomyces cerevisiae. Anal. Biochem. 2018, 563, 71-78. [CrossRef] [PubMed]

70. Neef, D.W.; Kladde, M.P. Polyphosphate loss promotes SNF/SWI-and Gen5-dependent mitotic induction of PHO5. Mol. Cell. Biol. 2003, 23, 3788-3797. [CrossRef]

71. Ault-Riché, D.; Fraley, C.D.; Tzeng, C.-M.; Kornberg, A. Novel assay reveals multiple pathways regulating stress-induced accumulations of inorganic polyphosphate in Escherichia coli. J. Bacteriol. 1998, 180, 1841-1847. [CrossRef]

72. Cyr, M.; Coutand, M.; Clastres, P. Technological and environmental behavior of sewage sludge ash (SSA) in cement-based materials. Cem. Concr. Res. 2007, 37, 1278-1289. [CrossRef]

73. Wang, S.; Xu, C.; Yu, S.; Wu, X.; Jie, Z.; Dai, H. Citric acid enhances the physical properties, cytocompatibility and osteogenesis of magnesium calcium phosphate cement. J. Mech. Behav. Biomed. Mater. 2019, 94, 42-50. [CrossRef] [PubMed]

74. Muller, F.; Mutch, N.J.; Schenk, W.A.; Smith, S.A.; Esterl, L.; Spronk, H.M.; Schmidbauer, S.; Gahl, W.A.; Morrissey, J.H.; Renne, T. Platelet polyphosphates are proinflammatory and procoagulant mediators in vivo. Cell 2009, 139, 1143-1156. [CrossRef]

75. Verhoef, J.J.; Barendrecht, A.D.; Nickel, K.F.; Dijkxhoorn, K.; Kenne, E.; Labberton, L.; McCarty, O.J.; Schiffelers, R.; Heijnen, H.F.; Hendrickx, A.P.; et al. Polyphosphate nanoparticles on the platelet surface trigger contact system activation. Blood 2017, 129, 1707-1717. [CrossRef] [PubMed]

76. Vimalraj, S. Alkaline phosphatase: Structure, expression and its function in bone mineralization. Gene 2020, 754, 144855. [CrossRef] [PubMed]

77. Murshed, M. Mechanism of bone mineralization. Cold Spring Harb. Perspect. Med. 2018, 8, a031229. [CrossRef]

78. Xia, Y.; Chen, H.; Zhang, F.; Bao, C.; Weir, M.D.; Reynolds, M.A.; Ma, J.; Gu, N.; Xu, H.H.K. Gold nanoparticles in injectable calcium phosphate cement enhance osteogenic differentiation of human dental pulp stem cells. Nanomedicine 2018, 14, 35-45. [CrossRef] 